\title{
Potensi antagonisme senyawa metabolit sekunder asal bakteri endofit dengan pelarut metanol terhadap jamur $G$. boninense Pat.
}

\author{
Fitri Widiantini, Endah Yulia, dan Ceppy Nasahi \\ Departemen Hama dan Penyakit Tumbuhan, Fakultas Pertanian, Universitas Padjadjaran \\ Jl. Raya Bandung-Sumedang KM 21, Jatinangor Jawa Barat 45363 \\ Alamat korespondensi: fitri.widiantini@unpad.ac.id
}

\begin{abstract}
Antagonism potency of secondary metabolites produced by endophytic bacteria in methanol against pathogenic fungi Ganoderma boninense Pat.
\end{abstract}

The research aimed to determine the antifungal effect of secondary metabolites produced by endophytic bacteria of healthy root oil palm tree against the growth of Ganoderma boninense, the causal agent of basal stem rot disease on oil palm tree. Endophytic bacteria isolates (BEK5, BEK6, BEK7, BEK8, BEK9, BEK10 dan BEK11) were grown on ISP2 agar media for 14 days and extracted using methanol. Following extraction, the methanol was evaporated using rotary evaporator and the filtrat was sterilized using membrane filter $0.2 \mu \mathrm{m}$. The effect of the secondary metabolites against $G$. boninense was tested using agar well diffusion method. The observation on the colony growth and morphologicy of $G$. boninense mycelia were done at 7 days after treatment. The result demonstrated that all of the endophytic bacteria were able to produce seconday metablites that has antifungal effect on the growth of $G$. boninense. The highest growth inhibition was shown by secondary metabolites produced by BEK6 with inhibition of $22.89 \%$. Furthermore, the secondary metabolites produced by all of the endophytic bacteria were caused morphological changes on the mycelia of $G$. boninense.

Keywords; Antifungal, Inhibition, Malformation

\begin{abstract}
ABSTRAK
Penelitian ini bertujuan untuk mengetahui kemampuan antijamur metabolit sekunder yang dihasilkan oleh bakteri endofit asal akar tanaman kelapa sawit untuk menghambat pertumbuhan jamur patogen Ganoderma boninense, penyebab penyakit busuk pangkal batang pada tanaman kelapa sawit. Isolat-isolat bakteri endofit (BEK5, BEK6, BEK7, BEK8, BEK9, BEK10 dan BEK11) ditumbuhkan pada media ISP2 agar selama 14 hari dan kemudain diekstraksi dengan pelarut metanol. Metanol diuapkan menggunakan rotary evaporator dan filtrat yang dihasilkan disterilkan menggunakan membran filter berukuran $0,2 \mu \mathrm{m}$. Pengujian pengaruh senyawa metabolit sekunder terhadap pertumbuhan jamur $G$. boninense dilakukan dengan metode agar well diffusion. Pengamatan terhadap pertumbuhan koloni jamur $G$. boninense dan morfologi miselia $G$. boninense dilakukan pada 7 hari setelah perlakuan. Hasil penelitian menunjukkan semua isolat bakteri endofit mengeluarkan senyawa metabolit sekunder yang dapat menghambat pertumbuhan jamur $G$. boninense. Penghambatan pertumbuhan koloni jamur $G$. boninense tertinggi sebesar 22,89\% ditemukan pada perlakuan metabolit sekunder asal bakteri BEK6. Pengamatan terhadap morfologi jamur $G$. boninense menunjukkan bahwa senyawa metabolit sekunder yang dihasilkan oleh isolat-isolat bakteri endofit tersebut dapat menyebabkan perubahan morfologi miselia $G$. boninense.
\end{abstract}

Kata kunci: Antifungal, Penghambatan, Malformasi 


\section{PENDAHULUAN}

Ganoderma boninense Pat. merupakan jamur patogen penyebab penyakit busuk pangkal batang pada tanaman kelapa sawit. Penyakit ini sangat merugikan karena ternyata dapat menyerang berbagai stadia pertumbuhan kelapa sawit dari pembibitan hingga saat tanaman mulai menghasilkan. Penyakit busuk pangkal batang ini dapat menyebabkan kehilangan hasil hingga mencapai 80\% (Susanto et al., 2005). Sebelumnya penyakit busuk pangkal batang dilaporkan hanya menyerang tanaman kelapa sawit yang sudah menghasilkan saja, akan tetapi dilaporkan bahwa penyakit busuk pangkal batang ini dapat menyerang tanaman muda yang berumur 1-2 tahun (Ishaq et al., 2014), yang sebetulnya dapat menyebabkan kerugian yang lebih besar karena harus dilakukan penanaman ulang (Susanto et al., 2005).

Penyakit ini relatif sulit untuk dikendalikan karena deteksi dini hampir tidak dapat dilakukan. Jamur $G$. boninense merupakan patogen tular tanah yang pada awal infeksi tidak menunjukkan adanya gejala. Jamur tumbuh di dalam jaringan tanaman sampai ketika sudah parah gejala eksternal baru dapat terlihat. Gejala eksternal penyakit busuk pangkal batang biasanya ditunjukkan dari adanya perubahan pertumbuhan dan dan tubuh buah jamur yang muncul pada pangkal batang tanaman kelapa sawit (Ishaq et al., 2014). Tanaman kelapa sawit muda yang terserang $G$. boninense, daunnya terlihat menguning atau bercak-bercak kekuningan (mottling) pada daun bagian bawah yang diikuiti dengan gejala nekrosis. Daun muda yang belum membuka menunjukkan gejala klorotik dan panjang daun berkurang. Seringkali diikuti gejala nekrotik pada ujung daunnya. Seiring dengan perkembangan penyakit, tanaman kelapa sawit tersebut akan terlihat pucat dengan pertumbuhan yang terhambat sementara daun tombak tidak terbuka. Gejala yang hampir sama juga dapat terlihat pada tanaman kelapa sawit yang lebih tua, dengan jumlah daun tombak yang tidak terbuka lebih banyak disertai adanya daun-daun kanopi yang terlihat pucat (Mih \& Kinge, 2015).

Pengendalian penyakit busuk pangkal batang ini masih mengandalkan pada aplikasi fungisida sistemik, meskipun sebenarnya kurang efektif. Sehingga pengendalian penyakit busuk pangkal batang lebih baik dilakukan dengan meningkatkan kesehatan tanaman kelapa sawit (Bivi et al., 2016). Penggunaan agens antagonis disinyalir selain dapat menghambat perkembangan patogen juga mempunyai efek lain terhadap tanaman, antara lain dengan meningkatkan ketahanan tanaman (Ahemad \& Kibret, 2014).

Bakteri endofit dilaporkan efektif dalam mengendalikan penyakit pada berbagai jenis tanaman dari rumput-rumputan hingga tanaman berkayu (Hushiarian et al., 2013). Penggunaan bakteri endofit untuk mengendalikan penyakit tanaman memiliki keuntungan lain karena bakteri endofit dikenal juga sebagai sumber penghasil senyawa-senyawa metabolit sekunder yang memiliki peran penting baik di dunia kesehatan maupun pertanian. Senyawa metabolit sekunder merupakan senyawa yang fungsinya dalam metabolisme primer bakteri belum diketahui secara pasti. Meskipun demikian, disinyalir senyawa metabolit sekunder yang dihasilkan oleh bakteri endofit berperan penting dalam interaksinya dengan baik lingkungan maupun tanaman inangnya (Brader et al., 2014). Senyawa-senyawa metabolit sekunder yang dihasilkan oleh bakteri dari golongan pseudomonads seperti phenazine, oomycin, hydrogen sianida dan pyoverdin dilaporkan bersifat anti jamur terhadap berbagai jenis patogen penting pada tanaman (ChinA-Woeng et al., 2003).

Beberapa isolat bakteri endofit asal akar tanaman kelapa sawit yang sehat telah diisolasi dan menunjukkan kemampuannya dalam menghambat pertumbuhan koloni jamur $G$. boninense secara in vitro (Nasahi et al., 2016). Perbanyakan isolat bakteri endofit tersebut dalam media ISP2 cair menunjukkan bahwa isolat-isolat bakteri tersebut mampu menghasilkan senyawa metabolit sekunder yang bersifat anti jamur terhadap $G$. boninenese (Widiantini dkk., in press). Akan tetapi, tidak semua senyawa metabolit sekunder yang dihasilkan dapat terlarut dalam air. Oleh karena itu perlu dilakukan penggunaan pelarut berbeda dalam mendeteksi senyawa metabolit sekunder yang mungkin dikeluarkan oleh bakteri-bakteri endofit tersebut yang tidak dapat dilarutkan dalam air. Penelitian ini bertujuan untuk mengetahui potensi senyawa metabolit sekunder yang dihasilkan oleh bakteri endofit asal akar kelapa sawit tersebut dalam menghambat pertumbuhan jamur $G$. boninense secara in vitro dengan menggunakan pelarut metanol. 


\section{BAHAN DAN METODE}

\section{Perbanyakan isolat bakteri endofit dan ekstraksi senyawa metabolit sekunder}

Bakteri yang digunakan dalam penelitian ini merupakan isolat koleksi lab Bioteknologi Proteksi Tanaman Fakultas Pertanian (BARK5, BARK6, BARK7, BARK8, BARK9, BARK10 dan BARK11) yang sebelumnya telah diketahui mempenyai efek penghambatan terhadap pertumbuhan G. boninense (Nasahi et al., 2016). Isolat-isolat bakteri endofit ditumbuhkan dan diperbanyak pada media ISP2 padat (yeast extract 4 $\mathrm{g}$, malt extract $10 \mathrm{~g}$, glucose $4 \mathrm{~g}$, agar $20 \mathrm{~g}$, akuades 1 $1, \mathrm{pH} 7,2 \pm 0,2)$. Isolat bakteri tersebut digoreskan pada permukaan media ISP2 secara penuh hingga tidak menyisakan ruang pada permukaan agar, kemudian diinkubasikan pada suhu ruang. Setelah 14 hari, media yang telah ditumbuhi isolat-isolat bakteri tersebut dipotong dadu dan dimasukkan ke dalam metanol dengan perbandingan 1:1 (w/v) yang kemudian kembali diinkubasikan dalam rotary shaking incubator pada suhu ruang dengan kecepatan $120 \mathrm{rpm}$ selama 7 hari. Senyawa metabolit sekunder dipisahkan dari agar dan sel-sel bakteri melalui penyaringan berseri yang dimulai dengan memisahkan sel dan agar dengan menyaring menggunakan kertas saring Whatman no 1 yang diikuti dengan sentrifugasi pada kecepatan $6000 \mathrm{rpm}$ selama 30 menit. Supernatant dipisahkan dari pellet dan dipindahkan pada tabung baru yang steril untuk kemudian dipisahkan dari metanol melalui proses evaporasi dalam rotary evaporator. Hasil yang diperoleh kemudian disterilkan dengan menggunakan membran filter berukuran 0,2 $\mu \mathrm{m}$ yang kemudian digunakan untuk pengujian selanjutnya (Jihani et al., 2012).

\section{Pengujian senyawa metabolit sekunder terhadap $G$. boninense}

Kemampuan senyawa metabolit sekunder yang dihasilkan oleh dalam menghambat pertumbuhan koloni jamur $G$. boninense dilakukan dengan menggunakan metode agar well diffusion (Balouiri et al., 2016). Sebanyak $30 \mu \mathrm{l}$ masing-masing filtrat dari bakteri endofit dimasukkan ke dalam lubang berukuran dimeter $6 \mathrm{~mm}$ dan ketinggian 5 $\mathrm{mm}$ pada cawan petri yang berisi media PDA. Lubang tersebut dibuat berjarak $3 \mathrm{~cm}$ dari pinggir cawan petri. Kemudian potongan $G$. boninense (diameter $6 \mathrm{~mm}$ ) yang sebelumnya telah ditumbuhkan pada media PDA diletakkan bersebrangan dari lubang berisi filtrat tadi berjarak 3 $\mathrm{cm}$ dari pinggir cawan petri. Pengujian dilakukan dalam empat replikasi.

Pengamatan dilakukan dengan mengukur pertumbuhan koloni jamur dan pengaruhnya terhadap morfologi miselia $G$. boninense secara mikroskopis serta membandingkan dengan pertumbuhan pada kontrol yang tidak diperlakukan dengan senyawa metabolit sekunder. Penghambatan pertumbuhan koloni jamur G. boninense dihitung dengan menggunakan rumus sebagai berikut:

$\mathrm{I}=\frac{c-t}{c} \times 100 \%$

\section{Keterangan:}

$\mathrm{I}=$ Persentase penghambatan

$\mathrm{t}=$ Jari-jari $G$. boninense pada perlakuan

$\mathrm{c}=$ Jari-jari $G$. boninense pada kontrol

\section{HASIL DAN PEMBAHASAN}

Tabel 1 menunjukkan pengaruh pemberian senyawa metabolit sekunder asal bakteri endofit akar kepala sawit yang ditumbuhkan pada media ISP2 agar dan diekstraksi dengan pelarut metanol. Semua isolat bakteri endofit dapat menghasilkan senyawa metabolit sekunder yang bersifat antagonis terhadap pertumbuhan jamur $G$. boninense, meskipun tingkat penghambatan yang dihasilkannya tidak terlalu tinggi. Penghambatan pertumbuhan jamur $G$. boninense yang paling tinggi dihasilkan oleh bakteri endofit BEK9 dengan tingkat penghambatan mencapai $22.89 \%$. Sementara tingkat penghambatan yang paling rendah ditunjukkan oleh senyawa metabolit sekunder yang dihasilkan oleh bakteri endofit isolat BEK11, dengan penghambatan sebesar $7,67 \%$.

Jenis pelarut yang berbeda akan menyebabkan senyawa yang dilarutkannya berbeda pula. Metanol merupakan pelarut yang dapat digunakan untuk melarutkan berbagai senyawa metabolit sekunder dengan kisaran yang luas. Ekstraksi tanaman Kirkia wilmsii dengan pelarut methanol menghasilkan jumlah senyawa yang lebih tinggi dibandingkan dengan ekstraksi menggunakan pelarut jenis lain (Chigayo et al., 2016). Beberapa senyawa metabolit sekunder berada dalam jumlah yang besar sementara senyawa lainnya berada dalam jumlah yang sedikit. Oleh karena itu teknik ekstraksi untuk mendapatkan senyawa-senyawa tersebut sangat penting (Joana Gil-Chávez et al., 2013). 
Ketika pertumbuhan jamur G. boninense dibiarkan memenuhi cawan petri, penghambatan pertumbuhan jamur $G$. boninense pada beberapa isolat tampak lebih baik dibandingkan dengan isolat lainnya. Senyawa metabolit sekunder yang dihasilkan BEK6, BEK8 dan BEK9 mampu menghambat pertumbuhan koloni jamur $G$. boninense. Sementara pada beberapa perlakuan lainnya, meski koloni jamur G. boninense tetap tumbuh akan tetapi miselianya tampak menipis. Hal ini terlihat pada perlakuan dengan senyawa metabolit sekunder yang dihasilkan oleh BEK5, BEK7, BEK10 dan BEK11 (Gambar 1).

Tabel 1. Pengaruh senyawa metabolit sekunder yang dihasilkan oleh bakteri endofit pada media ISP2 dengan ekstraksi pelarut methanol terhadap pertumbuhan jamur $G$. boninense pada 9 hari setelah perlakuan.

\begin{tabular}{ccc}
\hline Perlakuan & $\begin{array}{c}\text { Jari-jari miselia } \\
\text { G. boninense }(\mathrm{cm})^{*}\end{array}$ & $\begin{array}{c}\text { Penghambatan pertumbuhan miselia } \\
\text { G. boninense }(\%)\end{array}$ \\
\hline Kontrol & $4,50 \mathrm{c}$ & - \\
BEK5 & $4,05 \mathrm{~b}$ & 9,94 \\
BEK6 & $3,51 \mathrm{a}$ & 22,00 \\
BEK7 & $4,09 \mathrm{~b}$ & 9,22 \\
BEK8 & $3,53 \mathrm{a}$ & 21,56 \\
BEK9 & $3,47 \mathrm{a}$ & 22,89 \\
BEK10 & $4,10 \mathrm{~b}$ & 8,94 \\
BEK11 & $4,16 \mathrm{~b}$ & 7,67 \\
\hline
\end{tabular}

${ }^{*}$ Angka yang diikuti oleh huruf yang sama menunjukkan hasil yang tidak berbeda nyata berdasarkan uji lanjut Duncan dengan taraf nyata $5 \%$.

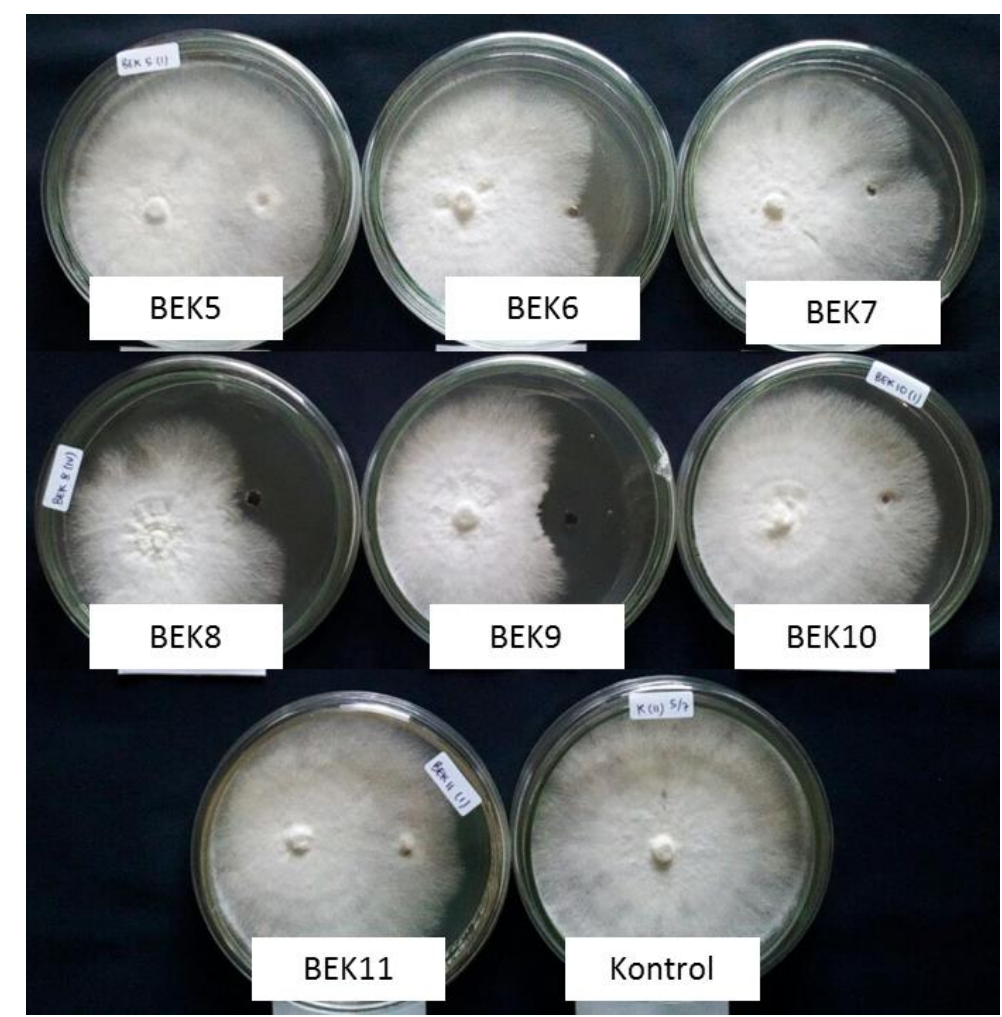

Gambar 1. Pengaruh senyawa metabolit sekunder asal bakteri endofit yang ditumbuhkan pada media ISP2 dan diekstraksi dengan pelarut methanol terhadap pertumbuhan jamur patogen $G$. boninense penyebab penyakit busuk pangkal batang pada tanaman kelapa sawit. 
Secara mikroskopis terlihat bahwa senyawa metabolit sekunder mempengaruhi morfologi miselia G. boninense (Gambar 2). Terdeteksi adanya perubahan morfologi miselia $G$. boninense pada semua perlakuan. Perubahan morfologi miselia yang terlihat antara lain miselia mengeriting (Gambar 2A, $2 \mathrm{C}, 2 \mathrm{~F}$ dan $2 \mathrm{G}$ ), melengkung berbalik arah (Gambar 2B, 2D, 2E dan 2G) dan menipis (Gambar 2D, 2E dan $2 \mathrm{G})$. Sementara pada perlakuan kontrol miselia $G$. boninense terlihat normal (Gambar $2 \mathrm{H})$. Senyawasenyawa kimia yang tersedia secara komersial untuk mengendalikan jamur patogen tanaman bekerja dengan mengganggu berbagai fungsi sel pada jamur.
Gangguan tersebut diantaranya dicirikan dengan berubahnya struktur miselia dan perkecambahan konidia jamur. Dilaporkan oleh Simionato et al. (2017) bahwa senyawa penazine yang dihasilkan oleh bakteri Pseudomonas aeruginosa mampu menghambat perkembangan jamur patogen Botrytis cinerea dengan mempengaruhi produksi eksopolisakarida (EPS). Miselia jamur B. cinerea terlihat mengkerut dan permukaannya menjadi tidak mulus. EPS sendiri merupakan salah satu faktor virulensi yang berperan dalam patogenisitas dari B. cinerea.

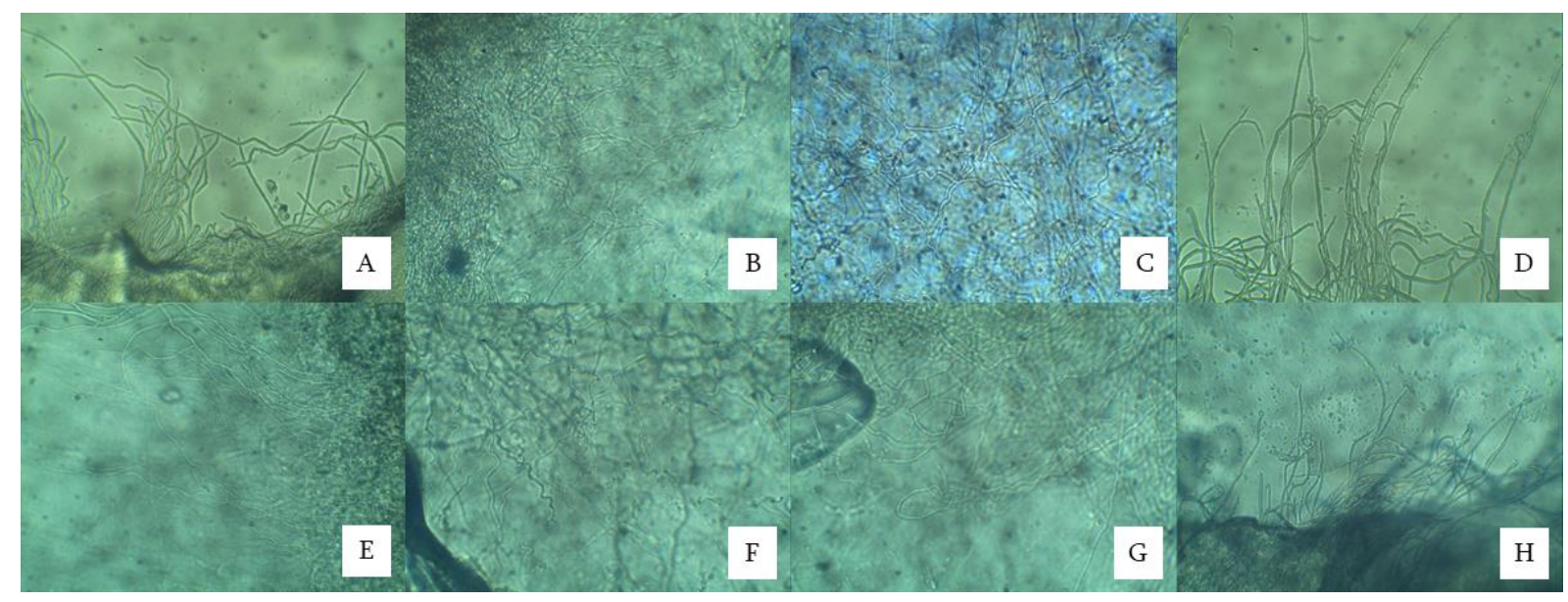

Gambar 2. Perbandingan morfologi miselia jamur $G$. boninense yang diperlakukan dengan senyawa metabolit sekunder yang dihasilkan oleh isolat bakteri endofit BEK 5 (A), BEK6 (B), BEK7 (C), BEK8 (D), BEK9 (E), BEK10 (F), BEK11 (G) dan Kontrol (H).

Senyawa metabolit sekunder yang dihasilkan oleh isolat-isolat bakteri endofit yang mempengaruhi pertumbuhan dan morfologi miselia $G$. boninense disinyalir dapat dimanfaatkan untuk pengendalian penyakit busuk pangkal batang pada tanaman kelapa sawit. Tingkat penghambatan pertumbuhan $G$. boninense oleh senyawa metabolit sekunder relatif berkurang seiring berjalannya waktu. Pada awal percobaan, tingkat penghambatan pertumbuhan relatif tinggi (data tidak ditampilkan). Pada akhir percobaan (9 hari setelah perlakuan), jamur $G$. boninense tumbuh lebih cepat pada semua perlakuan. Hal ini diduga karena senyawa metabolit telah menguap atau hilang efeknya sehingga $G$. boninense dapat tumbuh tanpa adanya hambatan. Lebih lanjut, senyawa metabolit yang dihasilkan pada percobaan ini diduga belum diproduksi secara optimal sehingga perlu dilakukan optimalisasi produksi senyawa metabolit sekunder. Kiranmayi et al. (2011) menyatakan bahwa kemampuan suatu mikroba untuk menghasilkan senyawa bioaktif sangat dipengaruhi oleh kandungan nutrisi dalam media dan beberapa faktor lingkungan seperti suhu, $\mathrm{pH}$ dan lamanya inkubasi.

\section{DAFTAR PUSTAKA}

Ahemad M, and M Kibret. 2014. Mechanisms and applications of plant growth promoting rhizobacteria: Current perspective. Journal of King Saud University - Science 26, 1-20.

Balouiri M, M Sadiki, and SK Ibnsouda. 2016. Methods for in vitro evaluating antimicrobial activity: A review. Journal of Pharmaceutical Analysis 6, 71-9.

Bivi MSHR, AS Paiko, A Khairulmazmi, MS Akhtar, and AS Idris. 2016. Control of 
basal stem rot disease in oil palm by supplementation of calcium, copper, and salicylic acid. The Plant Pathology Journal 32, 396-406.

Brader G, S Compant, B Mitter, F Trognitz, and A Sessitsch. 2014. Metabolic potential of endophytic bacteria. Current Opinion in Biotechnology 27, 30-7.

Chigayo K, PEL Mojapelo, S MnyakeniMoleele, and JM Misihairabgwi. 2016. Phytochemical and antioxidant properties of different solvent extracts of Kirkia wilmsii tubers. Asian Pacific Journal of Tropical Biomedicine 6, 1037-43.

Chin-a-Woeng TFC, GV Bloemberg, and BJJ Lugtenberg. 2003. Phenazines and their role in biocontrol by Pseudomonas bacteria. New Phytologist 157, 503-23.

Hushiarian R, NA Yusof, and SW Dutse. 2013. Detection and control of Ganoderma boninense: strategies and perspectives. SpringerPlus 2, 555.

Ishaq I, MS Alias, J Kadir, and I Kasawani. 2014. Detection of basal stem rot disease at oil palm plantations using sonic tomography. Journal of Sustainability Science and Management 9, 52-7.

Jihani S, K Brodolin, M Iraqui, S Ibnsouda, and A Haggoud. 2012. Isolation and molecular identification of antibioticproducing actinomycetes from an old house in the media of Fez, Morocco. African Journal of Microbiology Research 6, 7370-6.

Joana Gil-Chávez G, JA Villa, J Fernando Ayala-Zavala, J Basilio Heredia, D Sepulveda, EM Yahia, and GA González-Aguilar. 2013. Technologies for extraction and production of bioactive compounds to be used as nutraceuticals and food ingredients: An overview. Comprehensive Reviews in Food Science and Food Safety 12, 5-23.

Kiranmayi MU, P Sudhakar, K Sreenivasulu, and M Vijayalakshmi. 2011. Optimization of culturing conditions for improved production of bioactive metabolites by Pseudonocardia sp. VUK-10. Mycobiology 39, 174-81.

Mih AM, and TR Kinge. 2015. Ecology of basal stem rot disease of oil palm (Elais guineensis Jacq.) in Cameroon. American Journal of Agriculture and Forestry 3, 208-15.

Nasahi C, F Widiantini, E Yulia, R Meliansyah, dan $\mathrm{P}$ Rasisetyo. Isolasi dan deteksi potensi actinobacteria endofit dalam mengendalikan penyakit busuk pangkal batang pada tanaman kelapa sawit (Ganoderma boninense Pat.). In: Joko T, et al., eds. Proceedings of the Seminar Nasional Pengendalian Penyakit pada Tanaman Ramah Lingkungan II, 2016. Yogyakarta: Perhimpunan Fitopatologi Indonesia, 66-78.

Simionato AS, MOP Navarro, MLA De Jesus, AR Barazetti, CS Da Silva, GC Simões, MI Balbi-Peña, JCP De Mello, LA Panagio, RSC De Almeida, G Andrade, and AG De Oliveira. 2017. The effect of phenazine-1-carboxylic acid on mycelial growth of Botrytis cinerea produced by Pseudomonas aeruginosa LV strain. Frontiers in Microbiology 8.

Susanto A, PS Sudharto PS, dan RY Purba. 2005. Enhancing biological control of basal stem rot disease (Ganoderma boninese) in oil palm plantation. Mycopathologia 159, 153-7. 